This is a self-archived version of an original article. This version may differ from the original in pagination and typographic details.

Author(s): Münzel, Karla; Boon, Wouter; Frenken, Koen; Vaskelainen, Taneli

Title: Carsharing business models in Germany : characteristics, success and future prospects

Year: 2018

Version: Published version

Copyright: @ The Authors, 2017.

Rights: $C C B Y 4.0$

Rights url: https://creativecommons.org/licenses/by/4.0/

Please cite the original version:

Münzel, K., Boon, W., Frenken, K., \& Vaskelainen, T. (2018). Carsharing business models in Germany : characteristics, success and future prospects. Information systems and e-Business Management, 16(2), 271-291. https://doi.org/10.1007/s10257-017-0355-x 


\title{
Carsharing business models in Germany: characteristics, success and future prospects
}

\author{
Karla Münzel $^{1}$ (D) $\cdot$ Wouter Boon ${ }^{1} \cdot$ Koen Frenken $^{1} \cdot$ Taneli Vaskelainen $^{2}$
}

Received: 6 February 2017/Revised: 19 May 2017/ Accepted: 7 June 2017 /

Published online: 20 June 2017

(C) The Author(s) 2017. This article is an open access publication

\begin{abstract}
Carsharing provides an alternative to private car ownership by allowing car use temporarily on an on-demand basis. Operators provide carsharing services using different business models and ownership structures. We distinguish between cooperative, business-to-consumer (B2C) roundtrip and one-way, as well as peer-topeer (P2P) carsharing. This paper characterizes these different types of business models and compares their success in terms of diffusion using a comprehensive database of all 101 German carsharing providers in 2016. The key result holds that fleet size is significantly different across business models ranging from a few cars (cooperatives in small towns), to a few hundred (B2C roundtrip in larger cities), to over a thousand (B2C one-way in largest cities), up to multiple thousands (P2P across the country). By analyzing for each operator the number of cars per capita in the city they operate in, we do not find significant differences across business models indicating the viability of each separate business model type. Hence, we conclude that business models will continue to co-exist for a while, although some of the business models may well converge in the longer run due to Internet-ofThings applications and the introduction of self-driving cars.
\end{abstract}

Keywords Carsharing · Sharing economy · Platform economy · On-demand mobility services · Business models · Future mobility

Karla Münzel

k.1.munzel@uu.nl

1 Innovation Studies, Copernicus Institute of Sustainable Development, Utrecht University, Heidelberglaan 2, 3584 CS Utrecht, The Netherlands

2 School of Business and Economics, University of Jyväskylä, P.O.Box 35, 40014 Jyväskylä, Finland 


\section{Introduction}

In the last decade, the sharing economy has received a lot of attention given its promise of a scalable sustainable business model. The key to sharing is a higher utilization of goods by replacing permanent individual ownership by temporary ondemand access (Botsman and Rogers 2010). Carsharing is a key example of the sharing economy. It has been defined as a system that allows people to use locally available cars at any time and for any duration (Frenken 2015), and is often referred to as a prime example to explain the advantages of sharing over owning and exploiting underutilized assets (Botsman and Rogers 2010). Carsharing has the potential to satisfy individualized transportation demands in a sustainable and socially beneficial way, by decreasing the demand for cars, lowering emissions (using smaller and cleaner cars), reducing traffic and parking congestion, and increasing social cohesion amongst sharers (Prettenthaler and Steininger 1999; Loose 2010; Martin and Shaheen 2011; Shaheen and Cohen 2013; Chase 2015).

The aim of this study is to analyze and compare carsharing business models. We ask the question why different business models currently co-exist and how they perform. To this end, we compiled a comprehensive and detailed database of all carsharing providers in Germany, ranging from one-car organizations operating in small villages to large car manufacturers operating fleets of over a thousand cars. We distinguish between cooperative, business-to-consumer (B2C) roundtrip and one-way models, as well as peer-to-peer (P2P) carsharing. Our study contributes to research on the success of sharing economy services by comparing two success measures: absolute fleet size and relative fleet size, meaning cars per capita in the city of operation. We investigate the fit between different business models with different fleet sizes. From the relative fleet size, we can compare the local market presence of different business models. A second contribution to current literature is the explanation of the co-existence of carsharing business models. For this we analyze the entry patterns of firms to the carsharing sector including first-mover advantages. Through this, we are able to shed light on path dependencies and explain why no dominant design has emerged. Lessons about path dependence and first-mover advantages contribute to understanding the emergence of business models in the sharing economy and beyond.

Two key results emerge from the analysis. First, business models are very distinct in terms of their fleet size ranging from a few cars (operated by cooperatives in small towns), to a few hundred (B2C roundtrip in larger cities), to over a thousand (B2C one-way in largest cities), up to multiple thousands (P2P across the country). Second, although the business models differ markedly in terms of fleet size, they are equally competitive in terms of the number of cars they offer per capita in the geographical area they operate in. Hence, there is reason to believe that the various business models will continue to co-exist for a rather long time in their respective areas of operation.

We will proceed as follows. We provide a literature review on relevant carsharing research including the historical context of carsharing in Germany and a short overview of business model literature in general and carsharing business 
models in particular in Sect. 2. Then we go into the data collection and business model dimensions in Sect. 3. Then, Sect. 4 presents the empirical results on the business model dimensions per business model type and compares the success of each business model in terms of absolute and relative fleet size. Section 5 ends with a conclusion and a discussion of the prospects of each business model in the future and points out avenues for future research.

\section{Literature review}

\subsection{Development of carsharing}

Carsharing is a system that gives people the opportunity to use a car that is locally available for a demanded duration at any requested point in time. Carsharing has received considerable academic attention, motivated mainly by its environmental promise. Numerous studies have by now shown the positive environmental and transportation effect of carsharing. In the German context Loose (2016) calculates that one carsharing car situated in a city center replaces up to 20 private cars and that carsharing users reduced their car ownership by $62 \%$. A Dutch survey study (Nijland and van Meerkerk 2017) on carsharing users finds a 15-20\% reduction in car kilometers driven and car ownership to shrink from 1.12 to 0.72 cars per household after joining carsharing. Chen and Kockelman (2016) calculate the lifecycle impacts of carsharing on energy use and greenhouse gas emissions and also find positive impacts. The results suggest that persons joining carsharing decrease transportation energy use and emissions by $51 \%$. Other societal impacts, such as on employment and the overall economic situation, are still unclear. These aspects will likely see large changes as a result of further technological developments, in particular, the introduction of self-driving cars.

Carsharing started in the late $1980 \mathrm{~s}^{1}$ in Switzerland and Germany and was at first initiated in small projects of environment-minded groups (Shaheen et al. 1998). These early organizations were arranged in a Business-to-Consumer (B2C) form, in which the organization (operating for-profit or not-for-profit) owns a fleet of cars that the customers can use. Many of these cooperatives remain small as they are setup to serve a small group of users in a single town. Most organizations started out in environmentally concerned local communities that wanted to meet their mobility needs in a more sustainable way (Loose 2014a). Initially, the general business models of these organizations were fairly similar and were based on a roundtrip (RT) mode where cars have to be returned to the same spot at the end of the trip as where they were rented from.

Some of the grassroots operators achieved fast growth, partly driven by technological advances and professionalization of services. In particular, internet applications made booking procedures more efficient and user-friendly, while access to cars was improved through smart cards and later smart locks (Warmke and

\footnotetext{
1 Earlier experiments were set up in Switzerland (1948 Sefage), France (1972 Procotip) and the Netherlands (1973 Witkar) but failed to operate successfully and were suspended.
} 
Dannheim 2014). These growing organizations are located in mid-sized to large cities and often changed their cooperative status into a for-profit organization to enable further growth and professionalization. Alternatively, a range of grassroots organizations stayed small and continued as a local cooperative, mostly in small towns and villages. Next to the early grassroots organizations, large companies from related industries entered the carsharing market. In Germany this started with the entries of the national railway provider (Deutsche Bahn) in 2001 and oil company Shell in 2003. ${ }^{2}$ These kind of operators typically target larger cities than cooperatives where people are less dependent on car ownership.

The first B2C one-way carsharing operations started in 2008 (Daimler 2008) and were set-up mostly in the largest cities of a country. Different from the roundtrip mode, the one-way model allows cars to be dropped off anywhere in a designated city area (free-floating) or at a different station of the provider (station-based). Smartphone technology was of great importance for the larger diffusion of the oneway operations, since cars are not parked at a specific station but have to be located by the customers in an ad-hoc way. This business model type was clearly enabled through new app-based mobile technologies (Ehrenhard et al. 2017).

Around 2010, peer-to-peer (P2P) carsharing emerged as yet another business model. Companies operating under this business model provide a platform where private car owners and users can be matched and additional services like insurances are offered (Shaheen et al. 2012). P2P carsharing can therefore be characterized as a two-sided platform, where private consumers act as suppliers and consumers.

Technological advances will likely drive the further development of the carsharing industry in the near and longer future. One example is the current roll out of smart locks to be installed in privately owned cars. Further in the future selfdriving cars will bring unprecedented changes to the car system, and may well bring a further substitution of private ownership with a form of carsharing.

Carsharing itself is part of a wider set of developments known as 'shared mobility'. Another growing service that falls within the concept of shared mobility is ridesharing, where people share a ride in a car with a driver going a similar route as the passengers (e.g. the large European platform BlaBlaCar). Furthermore, ridehailing, where riders ask for a trip to a certain place from a driver who is providing an on-demand taxi service has also seen tremendous growth and attention (examples include Uber, Lyft, Didi). These developments, although related to carsharing, show different dynamics and are beyond the scope of the present study.

Even though the first carsharing operations started 30 years ago, it is still an emerging phenomenon. Carsharing operators are as yet in the process of developing and learning about their respective business models (Demil and Lecocq 2010; Sosna et al. 2010; Teece 2010). Furthermore, carsharing policy and regulations are still in the making (Delhaes 2016). The fluidity of markets, regulations and technologies may explain why carsharing lacks a "dominant design" (Murmann and Frenken 2006). Competing business models are indeed a typical feature for emerging technologies in service industries (Teece 2010; Boon et al. 2011), many expect a dominant business model to emerge due to the strong network externalities inherent

\footnotetext{
2 ShellDrive was taken over by Greenwheels in 2006.
} 
to ICT-based industries (Shapiro and Varian 1999). Indeed, a carsharing operator benefits from network externalities as a larger fleet size increases the proximity, availability and variety of cars on offer to its client. Hence, one can expect a selfreinforcing dynamic to occur, rendering larger operators to grow faster than smaller operators. Were such a "natural" monopoly to occur, the question is whether users are truly better off, meaning whether the positive externalities of larger operators outweigh monopoly fees charged by a dominant provider. Against this background, we consider our research question why different business models currently co-exist and how they perform, to be both important and timely.

\subsection{Business models}

According to Teece (2010, p. 174) a business model "yields value propositions that are compelling to customers, achieves advantageous cost and risk structures, and enables significant value capture by the business that generates and delivers products and services". There is not one established definition of what a business model is. Zott et al. (2011), Boons and Lüdeke-Freund (2013) and Osterwalder and Pigneur (2010) show that different dimensions and components are used to create business model frameworks. The definition provided by Teece shows three reappearing key elements: the value proposition, the value network and the revenue-cost model (value capture) (Chesbrough 2007; Teece 2010). The business model concept has become increasingly important with the development of internetbased business triggering fundamental changes in how firms create value (Amit and Zott 2001). Earlier value creation was often based on manufacturing a product and selling it to the customer. The digital economy provided new forms of value creation and networking between firms and among customers increased (Zott et al. 2011). The carsharing market is such an emerging industry associated with a broad network and innovative business models which are often heavily reliant on digital infrastructures.

In an emerging industry like carsharing many different business models can be found. Teece (2010) explains that in early stages of a new industry the 'fundamental truths' about the customers, the cost models and competitors still need to be explored. Currently, on the carsharing market there is a search for a generic model that could become the standard (Morris et al. 2005), which could subsequently lead to different firms operating under a single 'sharing' business model (Teece 2010). Also, a detailed view on the specific dimensions of each business model is important, since firms can use specific differences in their business model to gain an advantage over a competitor (Morris et al. 2005; Teece 2010) or speak to a different target group or in a different setting.

Business models play a central role in explaining firm success (Zott et al. 2011; Casadesus-Masanell and Ricart 2010; Markides and Charitou 2004). In particular, organizational success is impacted by the value creation when using an innovative business model (Morris et al. 2005; Patzelt et al. 2008). Since business models describe how resources are used, how value is created and offered, they are directly related to firm success. Defining the success of a firm, however, is not straightforward, especially in an emerging market like carsharing. Financial 
performance could be an indicator for success. Yet, to measure profits of companies in their founding stage is conceptually challenging, and access to reliable data for research purposes is difficult. The size of a firm, its spatial diffusion or market share are thus examples of alternatives. Next to data availability, the objectives and backgrounds of sharing economy firms differ and are not all based on a profit logic, given that cooperatives are driven more by environmental and social objectives. Their definition of success is thus less dependent on profits. Hence, in the analysis, we will rely on two alternative success measures based on the size of an organization's car fleet, which represent the size and diffusion of an organization.

The exploration of different business model possibilities on a new market can be heavily influenced by a firm's previous or main business model, a case of path dependence (Chesbrough and Rosenbloom 2002; Chesbrough 2010). The carsharing market (especially in Germany) is an interesting case to explore these interdependencies, because we see firms with diverse backgrounds. Many stand-alone carsharing operators ${ }^{3}$ and start-ups can be observed, as well as different incumbent ${ }^{4}$ backed firms coming from different industries (e.g. car manufacturers, rail operators or car rental firms), and other firms backed by local municipalities or utilities. This differing ability to use different sources of value creation is important (Chesbrough 2010). The background of a firm brings certain resources and routines with it, leading to a specific development path (Garud et al. 2010). We presuppose path dependence to have a large impact on the process of creating a business model for the carsharing market, for which reason we expect differences between firms from different backgrounds.

Path dependence plays out differently for incumbent and new-entry firms. Following Chesbrough and Rosenbloom (2002) we expect incumbents that enter the carsharing market to stay close to their current or main business model so that they are able to fit the new business model into their organization. We also expect them to use their inherent competences to gain advantages over competing firms. Incumbent players have a strong advantage with their high amount of resources that allows them to experiment with different models or to implement a larger system without having to slowly built up a car fleet (Sosna et al. 2010). At the same time, incumbents are constrained by their main business logic which predominates their decisions (Chesbrough 2010). Large incumbents following a strong market logic with a large interest in fast profitable growth might be steered into using certain business models which allow this. Compared to these arguments, newly-founded stand-alone carsharing firms are much less constrained by path dependencies but can invent completely novel, and even radical, business models (Chesbrough and Rosenbloom 2002). We expect them for example to build a novel partner-structure and to use new target groups. However, compared to incumbents, new firms may struggle to overcome entry barriers to the market given a lack of internal resources, which makes them less able to scale fast but also less able to experiment with

\footnotetext{
3 A stand-alone carsharing organization refers to an organization that is not owned by or closely connected to an incumbent firm (e.g., car manufacturer, car rental firm, transit operator).

4 In the following 'incumbent' is used when describing an incumbent firm already active in a different market (e.g., a large car manufacturer, a railway operator) which is operating on the carsharing market.
} 
different models over a long time. The scaling factor is of importance given the aforementioned network externalities in a market like carsharing.

Currently different types of carsharing business models seem to co-exist. As the carsharing industry lacks a dominant design, the current stage can be considered an era of 'ferment' (Utterback 1996). In the absence of a dominant design, investors remain reluctant to roll out a particular service to create a true mass market. Indeed, to date, carsharing has remained a very small market compared to the market of private car ownership or lease cars. In such an era of ferment, the entry barriers for new entrants remain low and the diversity of business models, each targeting specific user groups, remains high (Utterback 1996; Markides and Sosa 2013). One can expect therefore that entry numbers on the carsharing market remain high per year. At the same time, as explained before, carsharing is a market with strong network externalities as operators with a larger fleet size increase the proximity, availability and variety of their cars to their client. The benefits that larger operators bring to their users compare to smaller operators, creates a self-reinforcing rich-getricher dynamic where larger operators grow faster than smaller operators and entry barriers increase. Hence, early entrants profit from first-mover advantages in building up their car fleet and benefitting from this self-reinforcing logic. Thus, one can expect that the fleet size of older operators is larger than that of younger operators. Note, however, that while network externalities in carsharing are strong, these benefits are mainly confined to a single geographical market (town or city), as most users rent cars solely in the city or town of residence. Thus, in each geographical market, an early entrant has had more time to build up their local clientele and car fleet than later entrants. However, given that operators with different business models target different geographical markets (cooperatives in small towns, B2C roundtrip in larger cities, B2C one-way in largest cities, and P2P across the country), first-mover advantages are likely to exist among firms within each business model, but are not necessarily present at the level of the carsharing market as a whole.

This paper therefore explores the different business model types present on the German carsharing market, the differences in business model dimensions and differences in success. As part of analyzing the co-existence between business models we further investigated entry waves, firm-level path dependence and firstmover advantages.

\section{Research design}

We selected the German carsharing market to analyze the different business models in carsharing. Germany was chosen because of its dominant position in Europe in terms of being the largest carsharing market (Loose 2014b), its diverse spectrum of carsharing firms, and the interesting market outset with a large automotive industry and a strong 'car culture' (Germany Trade \& Invest 2016).

To distinguish between the main business model types, we built on work by Shaheen and Cohen (2013), Shaheen et al. (2006), Cohen and Kietzmann (2014), Clark et al. (2014) and Vaskelainen (2014) who classified business models in the 


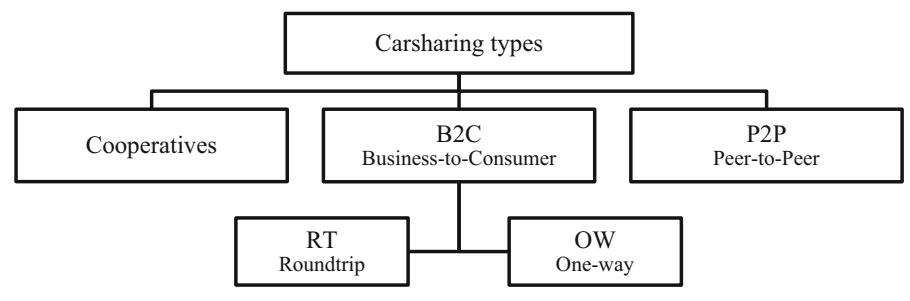

Fig. 1 Types of carsharing business models

carsharing market. Typically, the carsharing market is divided into three basic types: cooperatives with a communal interest to share cars and a not-for-profit orientation, B2C carsharing where a firm owns a fleet of cars which they rent out on-demand for short time periods and P2P carsharing where cars are shared between individuals and a firm acts as a mediating platform. The B2C business model is generally further divided into roundtrip and one-way models (Vaskelainen 2014; Shaheen et al. 2015) as shown in Fig. 1.

For each of the four business models, in line with existing literature on carsharing (Bohnsack et al. 2014; Cohen and Kietzmann 2014; Eschenbaecher et al. 2014; Gerwig et al. 2014; Vaskelainen 2014), we analyze the key business model dimensions. We used the three dimensions of value proposition, value network and value capture, that are reappearing in business model research, to categorize the design elements of the carsharing business models (Table 1). At this stage of the market development and with our focus on the operators we decided to analyze only these three main dimensions. ${ }^{5}$ The value proposition dimension shows what value is offered to the users and contains indicators on trip type, geographical membership span (operations in one city, on a national level or international), fleet ownership and fleet variety. The value network dimension shows how the organization is connected to other players in- and outside of the industry and includes indicators on the owner background and the partner network. The value capture dimension shows how and in what manner value is captured and includes indicators on profit orientation and the fee structure.

Figure 2 lays out the steps of the research explained in the following. Data was collected for all carsharing firms in Germany, which are accessible to the public and have an online homepage. The firms were identified through a member list of the Bundesverband Carsharing, the umbrella organization of German carsharing providers, that can be accessed on its website (Mitglieder; BCS) or through a systematic keyword search in public search engines (step 1). This leads to a total of 101 carsharing operators in Germany. The number of cars, the operating area and the founding year were collected through the firms' homepages or inquiries with the firms. Data on the defined business model dimensions and their indicators were systematically collected by analyzing the firms' homepages and were saved in a detailed database, in which we set up categorical variables for each indicator (step 2).

\footnotetext{
5 Some studies use the business model canvas instead (Osterwalder, Alexander; Pigneur 2010), which include some additional dimensions.
} 
Table 1 Business model dimensions and variables

\begin{tabular}{ll}
\hline Business model dimension & Indicators \\
\hline Value proposition & Trip type \\
& Membership span \\
& Fleet ownership \\
& Fleet variety \\
Value network & Owner background \\
Value capture & Partner network \\
& Profit orientation \\
& Fee structure \\
\hline
\end{tabular}

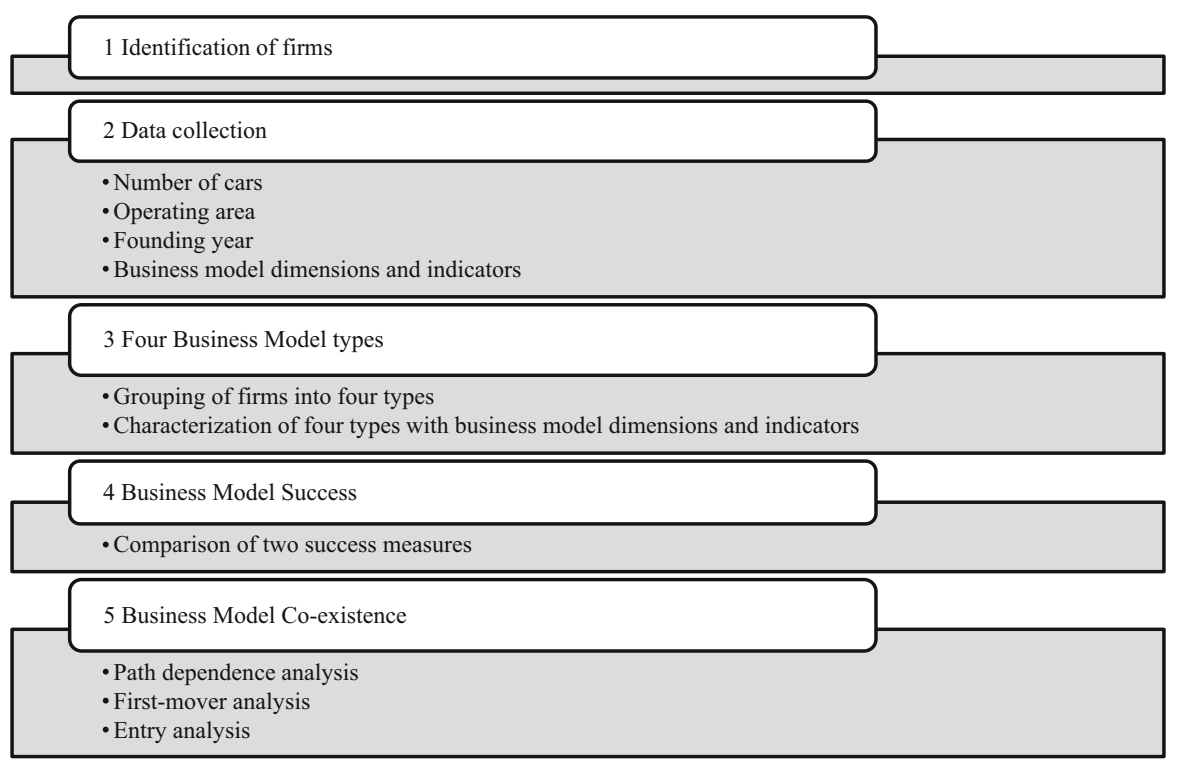

Fig. 2 Outline of research design

The firms in the database were grouped into the carsharing business model types as shown in Fig. 1. Because of the high level of detail on the business model dimensions and their indicators, this could be done without problems and every firm was clearly allocated to one of the business model types. There are some roundtrip companies that operate one-way carsharing as an additional service, for which the roundtrip mode is the main model and one-way operations can rather be described as experiments. Therefore, these firms are categorized as roundtrip providers. The resulting four groups we formed are: carsharing cooperatives, B2C roundtrip carsharing providers, B2C one-way carsharing providers and $\mathrm{P} 2 \mathrm{P}$ carsharing providers (step 3).

The 101 operators are then compared on the basis of two different success measures to analyze where systematic differences in success exist across business 
models (step 4). Firm success is often measured using financial indicators like revenue or profit. These numerical measures offer an easy comparison and clearly show how well a firm is able to use its business model to generate monetary value. As noted above, this is not the goal of all firms in the carsharing market as some of them have a not-for-profit intention. Furthermore, the carsharing industry is rather young and many firms are still in a growing phase, where profit or revenue might not be a good indicator for firm success and the success of a business model type. What is more, we could not use financial indicators to define firm success because data are not made available. The same applies to diffusion measures, like the number of customers or the number of bookings. Therefore, we pursued other firm success indicators: absolute and relative fleet size. First, all types of carsharing organizations share the objective of promoting carsharing for profit, environmental or social reasons. So, absolute fleet size gives an indication of the extent to which they have been successful in this. Second, as a relative measure we divided an operator's absolute fleet size by the number of inhabitants in the city or cities it is operating in. This measure, the ratio of cars per capita, provides an account of how dominant an operator is in the city or cities it is operating in, given the potential market size (number of inhabitants). Instead of only indicating the size of the operation, the ratio variable proxies market share. The different business model types have different sources of funding and revenues. Cooperatives for example do not need to make a profit, while organization with investors interested in profit have a larger interest in a smaller ratio of cars per people.

Step 5 focuses on investigating the co-existence of business models. We start with firm age, as surviving for a number of years can be an indicator for the achievements of a business model. Firm age further gives insights in possible firstmover advantages and entry patterns on the carsharing market. We study first mover advantages for the four business model types through comparing size (number of cars) and firm age, expecting older organizations to be larger. We analyze market entries and possible patterns of entry waves by visualizing entries per year for the four business model types. We additionally analyze path dependence using the business model dimensions and the owners background, financial possibilities and profit goals to identify differences in business model choices of e.g. incumbents and ideology-driven grassroots organizations.

\section{Results}

\subsection{Business model characterization}

The 101 identified carsharing organizations were allocated to the four business model types according to the general typology used in the literature and described in the previous chapter 3 . Table 2 shows the characteristics of these four types. Type 1 contains all firms operating as a cooperative, Type 2 contains all firms that operate with a B2C roundtrip model, Type 3 contains firms offering a B2C one-way service and Type 4 contains the firms operating as P2P carsharing platforms. It is clear that most organizations operate using the cooperative model (51 organizations) or the 
Table 2 Characteristics of carsharing business models

\begin{tabular}{|c|c|c|c|c|}
\hline Business model & $\begin{array}{l}\text { Type } 1 \\
\text { cooperatives }\end{array}$ & Type $2 \mathrm{~B} 2 \mathrm{C}$ roundtrip & Type 3 B2C one-way & Type 4 P2P \\
\hline Number of firms & 51 & 43 & 4 & 3 \\
\hline Average age & 13.3 & 10.4 & 4.8 & 5.7 \\
\hline $\begin{array}{l}\text { Average number } \\
\text { of cities } \\
\text { served }\end{array}$ & 1.2 & 7.2 & 3.5 & $\mathrm{n} / \mathrm{a}^{\mathrm{a}}$ \\
\hline $\begin{array}{l}\text { Average size of } \\
\text { cities served }\end{array}$ & 39,966 & 229,823 & $1,669,684$ & $\mathrm{n} / \mathrm{a}$ \\
\hline \multicolumn{5}{|l|}{ Value proposition } \\
\hline Trip type & Roundtrip & $\begin{array}{l}\text { Roundtrip } \\
12 \% \text { roundtrip and } \\
\text { OW (mostly } \\
\text { experiments) }\end{array}$ & One-way & Roundtrip \\
\hline $\begin{array}{l}\text { Membership } \\
\text { span }\end{array}$ & One city & $\begin{array}{l}77 \% \text { one city } \\
14 \% \text { national } \\
9 \% \text { international }\end{array}$ & $\begin{array}{l}2 \text { one city } \\
2 \text { international }\end{array}$ & International \\
\hline $\begin{array}{l}\text { Fleet } \\
\quad \text { ownership }\end{array}$ & Fleet owned by pro & vider & & $\begin{array}{c}\text { Cars owned } \\
\text { privately }\end{array}$ \\
\hline Fleet variety & $\begin{array}{l}\text { Varying car } \\
\text { models (if \# of } \\
\text { cars }>1 \text { ) }\end{array}$ & $91 \%$ varying models & $75 \%$ one-car model & $\begin{array}{l}\text { Varying } \\
\text { models }\end{array}$ \\
\hline \multicolumn{5}{|l|}{ Value network } \\
\hline \multirow[t]{2}{*}{$\begin{array}{l}\text { Owner } \\
\text { background }\end{array}$} & Non-incumbent & $\begin{array}{l}88 \% \text { non-incumbent } \\
12 \% \text { incumbent }\end{array}$ & $\begin{array}{l}75 \% \text { incumbent } \\
\text { owner }\end{array}$ & $\begin{array}{l}\text { Carsharing } \\
\text { startups }\end{array}$ \\
\hline & carsharing startups & $\begin{array}{l}74 \% \text { carsharing } \\
\text { startups } \\
4 \text { utility } \\
3 \text { car rental } \\
2 \text { car manufacturer } \\
1 \text { car dealer } 1 \text { rail } \\
\text { operator }\end{array}$ & $\begin{array}{l}1 \text { car manufacturer } \\
2 \text { car } \\
\text { manufacturer/car } \\
\text { rental joint ventures } \\
1 \text { carsharing startup }\end{array}$ & $\begin{array}{l}\text { All carsharing } \\
\text { startups }\end{array}$ \\
\hline Partners & $\begin{array}{l}12 \% \text { public transit } \\
24 \% \text { city-related } \\
\text { partners }^{\mathrm{b}}\end{array}$ & $\begin{array}{l}42 \% \text { public transit } \\
40 \% \text { city-related } \\
\text { partners } \\
19 \% \text { car-related }^{\text {cartners }}{ }^{c}\end{array}$ & $\begin{array}{l}100 \% \text { public transit } \\
50 \% \text { city-related } \\
\text { partners } \\
50 \% \text { car-related } \\
\text { partners }\end{array}$ & $\begin{array}{l}1 \text { city-related } \\
\text { partner }\end{array}$ \\
\hline
\end{tabular}

Value capture

Profit Not-for-profit For-profit


Table 2 continued

\begin{tabular}{lllll}
\hline Business model & $\begin{array}{l}\text { Type 1 } \\
\text { cooperatives }\end{array}$ & Type 2 B2C roundtrip & Type 3 B2C one-way & Type 4 P2P \\
\hline Fee structure & $\begin{array}{c}2 / 3 \text { registration } \\
\text { fee }\end{array}$ & $\begin{array}{l}\text { 64\% registration fee } \\
78 \% \text { monthly fee }\end{array}$ & $\begin{array}{l}100 \% \text { registration fee } \\
\text { 93\% monthly fee }\end{array}$ & $\begin{array}{l}\text { No } \\
\text { registration }\end{array}$ \\
& Hour fee & 100\% no monthly fee & $\begin{array}{l}\text { ree } \\
\text { fee }\end{array}$ \\
& & & $\begin{array}{c}\text { No monthly } \\
\text { fee }\end{array}$ \\
& & & $\begin{array}{c}\text { Hour or part- } \\
\text { day/day } \\
\text { prices }\end{array}$ \\
\hline
\end{tabular}

\footnotetext{
a $\mathrm{P} 2 \mathrm{P}$ carsharing is offered all over Germany, since a private car owner in any location can register his or her car on the platform. Therefore no precise data is collected on the number of cities where P2P carsharing is offered

b City-related partners include municipalities, local utilities, building associations

c Car-related partners include car dealers, car leasing companies, car rental companies
}

B2C roundtrip model (43). These business models are also the most established as evidenced by the high age of cooperatives and B2C roundtrip organizations. These companies mostly operate in a single city or region. Only a few firms operate according to the B2C one-way model (4) or the peer-to-peer model (3) and these firms were established more recently. The one-way operators are active in the largest German cities.

Type 1 contains 51 cooperatives operating without a profit motive. Interestingly, all run a roundtrip model. Most operate without partners and, if any, partners are from the local town. Two-thirds of the cooperatives require a registration fee and $78 \%$ a monthly fee. This underlines the community aspect where members pay a fee and hereby support the initiative even when usage is low.

Type 2 is made up of 43 for-profit firms offering B2C roundtrip carsharing. Next to the roundtrip model, $12 \%$ of the firms also offer one-way carsharing modes as a secondary 'experimental' service. B2C roundtrip is the least standardized business model. Most operate in only one city, while others operate nationally or even internationally. Most offer varying car models, varying fee structures, and varying network partners.

Type 3 includes four B2C one-way operators. Two of these operate on a small scale in one city only, two operate internationally. Three only offer one car type, while one offers varying models. Three of the firms are owned by car manufacturers, one is a carsharing startup without a parent company. All work together with public transit partners to facilitate multi-modal mobility and all firms require a registration fee, no monthly fee and charge per minute.

Type 4 includes the three P2P providers operating in Germany at the moment. All firms are international and have no incumbent parent company. Few partners can be identified and no registration fee or monthly fees are charged. Prices are usually per hour or per day.

We can observe differences in the business model dimensions of the different types in the obvious variables on which they are divided, namely trip type, fleet 
Table 3 Success of operators according to carsharing business models

\begin{tabular}{lllll}
\hline & $\begin{array}{l}\text { Type 1 co-ops } \\
(n=51)\end{array}$ & $\begin{array}{l}\text { Type 2 B2C roundtrip } \\
(n=43)\end{array}$ & $\begin{array}{l}\text { Type 3 B2C one-way } \\
(n=4)\end{array}$ & $\begin{array}{l}\text { Type 4 P2P } \\
(n=3)\end{array}$ \\
\hline Average number of cars & 11 & 200 & 1642 & 5006 \\
Cars/1000 people & 0.53 & 0.21 & 0.26 & 0.06 \\
\hline
\end{tabular}

ownership and profit goal, but also in other variables: the membership span of the cooperatives (Type 1) and most roundtrip providers (Type 2) is one city only. Most providers in these two types are not backed by a larger parent company but were founded as carsharing-dedicated startups (often driven by environmental motives). The firms in the one-way type (Type 3), by contrast, are mainly operated by incumbents and have the most extensive partner network, including in particular public transport organizations. The P2P type (Type 4) deviates: few partnerships were detected apart from those with insurance companies. This can be understood from the fact that the fleet is provided by individual car owners who are difficult to direct and control. The fee structure of Type 1 and 2 is mostly dominated by hourly fees, whereas the one-way type charges minute fees. No monthly fees are charged in the one-way type. These differences in fee structure are another indicator of the differential usage scenarios of one-way carsharing compared to the roundtrip types.

\subsection{Business model success}

Based on the differentiation into four business models, we are able to compare the success of the 101 carsharing operators. Table 3 shows the mean size of operators per business model type in terms of two success variables: fleet size, and fleet size per capita. The business model types clearly differ in the average number of cars that operators offer to their users. An ANOVA test shows that the differences are indeed significant at the $1 \%$ level. Cooperative firms operate with the lowest number of cars on average, generally only running in one small city. Recall that cooperatives are also the oldest operators on average. Hence, their small size and high age suggest cooperatives have little growth ambition; instead they are not-forprofit and rooted in a local community. B2C roundtrip providers operate many more cars with an average of 200 cars per firm. The variance is quite large with operators in a single city having only 45 cars on average, while roundtrip operators operating on a national scale naturally having much larger fleets with on average 713 cars. The four B2C one-way operators have a very large fleet with 1642 cars on average. This is made possible by the density benefits in large cities in which the one-way model is viable. Finally, P2P platforms offer by far the largest number of cars. This can be explained by the zero marginal costs of car owners in supplying their car. ${ }^{6}$

\footnotetext{
${ }^{6}$ Note, however, that the number of cars offered by peer-to-peer platforms does not imply that all cars are rented out frequently. While cooperatives and B2C business model providers can be assumed to offer cars only at locations where demand is sufficient at least to break even, many P2P cars are also offered at locations with little or no demand, because a private car owner does not bear any marginal cost by supplying the car.
} 
Turning to the number of cars per capita, the results are rather different. Here, an ANOVA test did not show significant differences between the four types of operators, even at the $10 \%$ level. The ratios, though, seem to suggest that cooperatives have a higher density of cars in the cities they operate in compared to other operators. This can be understood as a sign of inefficiency, which can be explained by the lack of a profit motive. By far the lowest rate of cars per people in the operating area is observed for Type 4 but the low rate has to be interpreted with care since the number of cars shared through a P2P platform was divided by the total German population as cars are offered throughout the whole of Germany. ${ }^{7}$

The interesting conclusion that can be drawn from the highly significant differences in terms of fleet size and from the insignificant differences in terms of number of cars per capita, is that different business models are present in cities of different size, while being equally viable in terms of coverage in the cities they operate in. Cooperatives occupy the niche of small towns that larger operators avoid due to a lack of scale economies and profit opportunities. B2C roundtrip operators typically serve in one or more medium-sized cities with a sizeable fleet and a more professional and impersonal business model. B2C one-way operators focus on the largest cities where density of usage is high enough to warrant the one-way concept such that coverage around the city remains secured. Finally, P2P carsharing is essentially "agnostic" regarding the locations in which it is used, as private car owners themselves decide to offer their car or not at zero marginal cost. Hence, supply occurs everywhere where car owners live and, thus, is viable both in any urban and rural environment.

\subsection{Business model co-existence}

In line with the theory of path dependence, we can observe that incumbents from related industries use some of their specific resources and competences when choosing a business model type for the carsharing market. For example, the national railway leverages its national network to set up carsharing in many towns and cities through initially stationing shared cars at the railway stations using the B2C roundtrip model. They further rely on their classic customer groups by focusing advertising for carsharing as part of an integrated multi-modal mobility solution. Car manufacturers and car rental organizations on the other hand build on their existing competences in producing and management of large car fleets, respectively, which explains why they choose for a fast and large-scale roll-out of cars made possible by the one-way business model. Finally, we did not observe incumbents entering the $\mathrm{P} 2 \mathrm{P}$ business model, which can be explained by the radically new ("disruptive") nature of $\mathrm{P} 2 \mathrm{P}$ sharing. Instead, we observe solely startups in the P2P segment. They were able to enter despite a lack of financial resources by facilitating private car owners to offer their own cars as the key resources using a two-sided P2P platform model.

\footnotetext{
7 Therefore, we also ran the ANOVA test for business model types 1, 2 and 3 only. Again, results proved insignificant at the ten percent level.
} 
Furthermore, we can ask the question whether operators benefit from first-mover advantages. This can be indicated by computing the correlation between fleet size and age. Looking at all 101 organizations, we find a negative (-0.09) but insignificant correlation. This suggests that at the level of the industry as a whole, operators do not benefit from first-mover advantages. Indeed, as is evident from Table 2, recent entrants adopting the B2C one-way and P2P business model have been able to establish very large car fleets in a short period of time, outnumbering cooperatives and most $\mathrm{B} 2 \mathrm{C}$ roundtrip providers. However, when looking at the correlation between size and age of operators for each business model type separately, we find positive correlations for cooperatives $(+0.39)$ and $\mathrm{B} 2 \mathrm{C}$ roundtrip operators $(+0.33)$. These correlations are significant at the 1 percent and 10 percent level, respectively. Correlations between size and age for B2C one-way and P2P operators were also found to be positive $(+0.75$ and +0.87$)$, but statistically insignificant (which is not surprising given the very low number of B2C one-way and $\mathrm{P} 2 \mathrm{P}$ operators). Hence, our hypotheses that first-mover advantages exist, is confirmed, but is confined to each business model. This result can be further illustrated by plotting size and age for each of the four business models in Fig. 3 . We choose here to plot the logarithm of fleet size given the outliers. The patterns show that for each business model the largest firms tend to be the older firms, while this patterns cannot be discerned for the population as a whole.

Finally, one can analyze the entry patterns over time. Figure 4 illustrates the times of entry of all operators of the four business models. In the beginning we see a cluster of cooperatives and B2C Roundtrip providers entering the market 20-25 years ago. The operators using the one-way type only started 1-8 years ago and the P2P providers 5-6 years ago. For the P2P type no very recent entrants are observed which could indicate strong scaling effects due to network externalities, raising the barriers to entry for new entrants. Interestingly, we observe again larger numbers of cooperative and B2C Roundtrip entrants during the past five

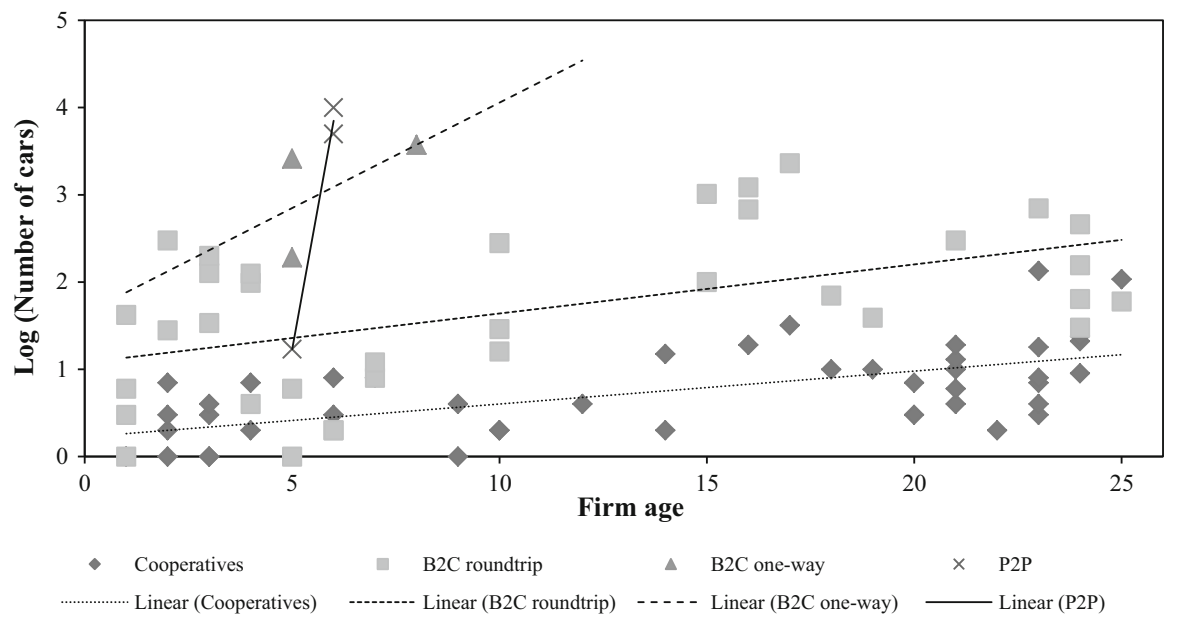

Fig. 3 Relation between fleet size and firm age for the different business model types 


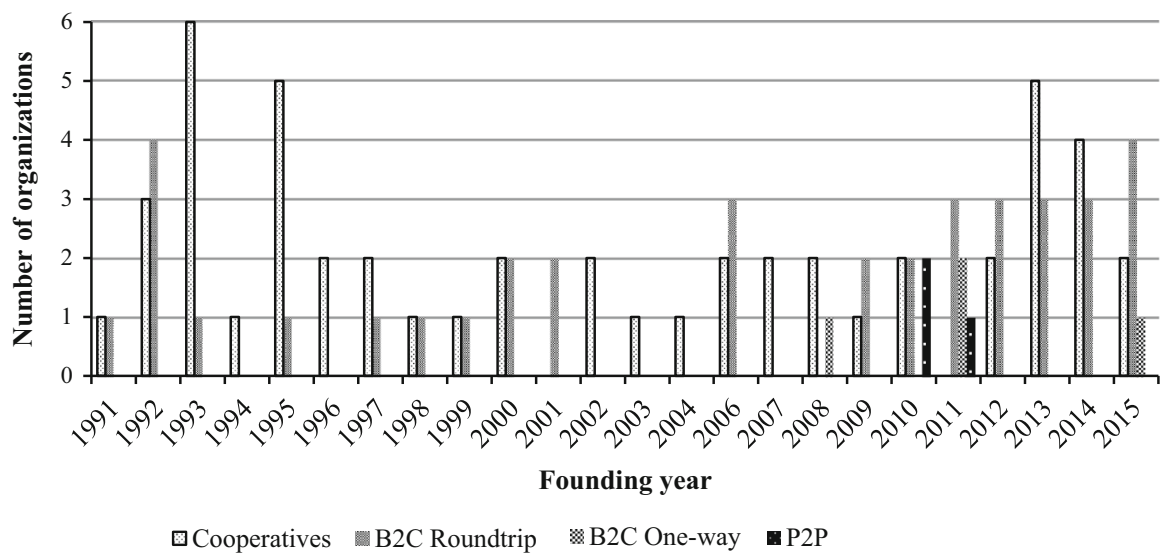

Fig. 4 Entry analysis. Number of organizations entering the market per year

years. This could be explained through spillover effects, where the rise in attention to carsharing, through the larger roll-outs of the one-way and $\mathrm{P} 2 \mathrm{P}$ operators, also brings attention back to the older types of carsharing. There are no significant differences in the characteristics of the business model between older cooperatives and roundtrip providers and their recent counterparts.

More generally, the continuous entry of cooperatives and B2C roundtrip organizations throughout the whole period likely reflects the low barriers to enter with these business models, in contrast to high barriers to enter with a B2C one-way and P2P business model. Software that is shared between providers (Schwarz et al. 2014) could also be another factor intensifying collaboration between providers rather than intensifying competition leading to exits. Thus, the overall tendency over the past 25 years is one that, at least for now, does not follow dominant design theory, which predicts that entry would decrease over time as a dominant design emerges and barriers to entry increase (Utterback and Suárez 1993; Klepper 1996).

\section{Conclusions and future prospects}

Using a new comprehensive database on all 101 German carsharing providers in 2016, we have been able to analyze four carsharing business model types in terms of their characteristics and success. The key results hold that fleet size is significantly different across business models, ranging from a few cars (cooperatives in small towns) to a few hundred (B2C roundtrip in larger cities) to over a thousand (B2C one-way in largest cities) up to multiple thousands (P2P across the country). By contrast, when analyzing for each operator the number of cars per capita in the city they operate in, we do not find significant differences across business models. The latter result indicates that each business model is viable, but in different types of urban environments. The more general conclusion that can be drawn from the results thus holds that business models will continue to co-exist for a while. Since 
the business models each occupy different city niches that only partially overlap, the viability of operators in each of the four business models seems secured, at the least in the short-term.

Given the advantages of all carsharing business model types in different urban environments, one cannot expect a convergence towards one dominant business model in the short run, as predicted by the standard model of industry evolution based on network externalities associated with a dominant design. In contrast to manufacturing products where firms benefit from adopting global technical standards making up a "dominant design" (Murmann and Frenken 2006), carsharing operators only benefit from local network externalities in the geographical market that they serve. As we have shown, network externalities can explain why older firms within each business model type have grown larger than their competitors adopting the same business models, indicating a first mover advantage inside of each business model type. However, at the level of the industry as a whole, first mover advantages are absent as the industry is geographically segmented along the four business model types with cooperatives dominating small towns, B2C roundtrip the larger cities, B2C one-way the largest cities, and P2P cars being spread out over the whole country. Another interesting observation are spillover effects that occur through the popularity and attention around the large one-way and P2P systems to the older carsharing types of cooperatives and B2C roundtrip carsharing, as indicated by a recent rise of entries in the latter categories. This trend of new local carsharing organizations might continue, especially in smaller towns and cities where the large providers do not meet their growth and profitability demand. We conclude that the theory of dominant design is not always applicable in its simple format of exploration phase, formation of a dominant design and a following shakeout. There are exceptions, especially in the innovative service sector and in new types of markets as the sharing economy. This study thus provides indicative evidence that not all sharing economy sectors are prone to natural monopolies and winner-takes-all dynamics, because network externalities are tied to the local level.

With ongoing technological advances and continuous entry, business models can be expected to evolve (Markides and Sosa 2013). Possibly, future developments in technologies and business operations may still lead to convergence in the longer run, for a number of reasons. The $\mathrm{P} 2 \mathrm{P}$ model is potentially the most disruptive as prices lie well below B2C models. Private car owners have purchased their vehicle for other purposes than rental and thus they usually are not aiming to profit from a car, but to make a little extra income. Thus, the rental prices are generally lower than the B2C alternatives. P2P carsharing can get a further boost when private lease companies integrate $\mathrm{P} 2 \mathrm{P}$ sharing into their business by incentivizing their leasers to rent out their cars at times they do not make use of the car. Finally, once private cars (and lease cars) have smart locks by default or other viable ways to remove the personal key exchange between car owner and user, the convenience of locating and opening a $\mathrm{P} 2 \mathrm{P}$ shared car will approach the current convenience levels of B2C cars. Hence, the prospects of $\mathrm{P} 2 \mathrm{P}$ sharing are advantageous and $\mathrm{P} 2 \mathrm{P}$ carsharing can become a serious rival of $\mathrm{B} 2 \mathrm{C}$ business models in small and large cities. Cooperatives may nevertheless continue to operate even if $\mathrm{P} 2 \mathrm{P}$ grows, if their members remain loyal to the ideological and environmental principles of joint 
ownership. Ideology may also extend to data ownership in the future, where consumers concerned about privacy may prefer a small, not-for-profit cooperative over a large and commercially oriented P2P platform. Cooperatives and small roundtrip providers will profit further from collaboration, e.g., through open-source software systems or partner tariffs to permit the use of shared cars in other cities.

Further in the future, however, P2P may be overtaken again by the one-way model. Once self-driving cars will diffuse, it is unlikely that people will own such cars. Rather, self-driving cars are commercially best exploited in a one-way business model, picking up nearby passengers and dropping them off at the desired location (International Transport Forum 2015). Also note that one-way, self-driving shared cars would substitute for taxi services and ride-hailing services such as Uber and Lyft. This scenario does thus not solely affect the future of carsharing, but of the entire car transportation system. A fusion of the taxi, ride-hailing and carsharing markets will lead to a single market with strong externalities, rendering a dominant design more likely. In such a scenario, the P2P business model in cities may only be limited to those who wish to drive a car themselves. The traditional roundtrip and also the P2P carsharing systems might remain viable longer in rural areas and for long-distance transportation, since an automated shared car system will take longer to become profitable in such market segments. Only if an automated shared car system becomes organized nationally or internationally, it could take over the remaining segments as well.

The analysis of this paper does have some limitations, mostly due to data restrictions. Success could only be measured with non-financial indicators and future research could benefit greatly from more data on the performance of the carsharing providers. It also has to be noted that the numbers of cars do not equal the usage of them and is likely different between the business model types. In particular, usage of P2P cars is considerably lower than for other business models. We further note that only firms with an internet presence were included in the database which possibly leads to the exclusions of smaller, community focused carsharing initiatives without a website. The carsharing market in Germany is a rather specific case, in particular given its strong cooperative tradition. Specific findings may not be easily generalizable to other countries. The larger trends and geographies identified on the other hand escape institutional or cultural contexts and may well be transferred to other settings and, to some extent, to other sharing economy sectors. It is especially interesting to see what roles new technologies can play in the developments of sharing markets.

Our database delivered explorative insights into the different types of business models on the German carsharing market, their diffusion, size and organization characteristics. We gained some first insights in path dependencies, entry conditions and possible future developments. These findings, together with improved datasets, open an array of possible future research questions into carsharing or the sharing economy in general. One possible improvement to this study lies in the definition of success and variables to measure success. Comparable financial data of all firms would make it possible to compare the types on their financial success, while data on the number of customers and the number of bookings would make it possible to compare them in terms of diffusion success. Besides more variation in the 
dependent variable of success or diffusion, the description of an organization's business model and capabilities can be more elaborated, for example, by including information on an organization's mission, financial structure and ownership structure, as well as founder characteristics to gauge pre-entry experience. Also, a systematical longitudinal analysis of the changes in business model indicators could give interesting insights. And, for a comprehensive analysis of carsharing organizations and their performance, the local context in which they operate deserves more attention. In particular, niche markets (e.g., students in university cities), the presence of competitors as well as engagement in local partnerships all affect the viability of a particular business model. Finally, future research efforts can be directed at extending the data to other countries to understand to what extent national (regulatory) contexts affect the viability of business models and the size of the car sharing market in total.

Notwithstanding the limitations and its exploratory nature, our study gives insights into the different types of carsharing business model, their diffusion and success. Our results suggest that the current diversity in business models is likely to persist in the near future, even if technological advances may eventually boost the $\mathrm{P} 2 \mathrm{P}$ and one-way business models in the longer run. Our main contribution has thus been empirical, yet motivated by more general theories about dominant design, firstmover advantage and path dependence. The challenge for future research will be to come up with more detailed data about carsharing organizations and their success, which would allow for explanatory analysis and prospective modelling.

Acknowledgements We thank Jan Blomme, Sam de Haas van Dorsser and Dennis van der Linden for their research assistance. Funding has been provided by Dialogic, the Rathenau Institute, and NWO under the "Sustainable Business Models" program (No. 438-14-904).

Open Access This article is distributed under the terms of the Creative Commons Attribution 4.0 International License (http://creativecommons.org/licenses/by/4.0/), which permits unrestricted use, distribution, and reproduction in any medium, provided you give appropriate credit to the original author(s) and the source, provide a link to the Creative Commons license, and indicate if changes were made.

\section{References}

Amit R, Zott C (2001) Value creation in E-business. Strateg Manag J 22:493-520. doi:10.1002/smj.187 Bohnsack R, Pinkse J, Kolk A (2014) Business models for sustainable technologies: exploring business model evolution in the case of electric vehicles. Res Policy 43:284-300. doi:10.1016/j.respol.2013. 10.014

Boon WPC, Moors EHM, Kuhlmann S, Smits REHM (2011) Demand articulation in emerging technologies: intermediary user organisations as co-producers? Res Policy 40:242-252. doi:10.1016/ j.respol.2010.09.006

Boons F, Lüdeke-Freund F (2013) Business models for sustainable innovation: state-of-the-art and steps towards a research agenda. J Clean Prod 45:9-19. doi:10.1016/j.jclepro.2012.07.007

Botsman R, Rogers R (2010) What's mine is yours: the rise of collaborative consumption. HarperBusiness, New York

Bundesverband Carsharing BCS Mitglieder. https://carsharing.de/verband/wir-ueber-uns/mitglieder. Accessed 15 Jan 2016 
Casadesus-Masanell R, Ricart J (2010) From strategy to business models and onto tactics. Long range plan 43:195-215. doi:10.1016/j.lrp.2010.01.004

Chase R (2015) Peers Inc: how people and platforms are inventing the collaborative economy and reinventing capitalism. PublicAffairs, New York

Chen TD, Kockelman KM (2016) Carsharing's life-cycle impacts on energy use and greenhouse gas emissions. Transp Res Part D Transp Environ 47:276-284. doi:10.1016/j.trd.2016.05.012

Chesbrough H (2007) Business model innovation: it's not just about technology anymore. Strateg Leadersh 35:12-17. doi:10.1108/10878570710833714

Chesbrough H (2010) Business model innovation: opportunities and barriers. Long Range Plan 43:354-363. doi:10.1016/j.lrp.2009.07.010

Chesbrough H, Rosenbloom RS (2002) The role of the business model in capturing value from innovation: evidence from Xerox Corporation's technology spin-off companies. Ind Corporate Change 11:529-555. doi:10.1093/icc/11.3.529

Clark M, Gifford K, LeVine S (2014) The usage and impacts of emerging carsharing business models: evidence from the peer-to-peer and business-to-business market segments. In: Transportation research board 93rd annual meeting, pp 14-1714

Cohen B, Kietzmann J (2014) Ride on! mobility business models for the sharing economy. Organ Environ 27:279-296. doi:10.1177/1086026614546199

Daimler (2008) Daimler startet Mobilitätskonzept für die Stadt: Car2go—so einfach wie mobiles Telefonieren. http://media.daimler.com/marsMediaSite/ko/de/9914253. Accessed 30 Jan 2017

Delhaes D (2016) New law set to boost carsharing. In: Handel. Glob. https://global.handelsblatt.com/ companies-markets/new-law-set-to-boost-carsharing-596610. Accessed 30 Jan 2017

Demil B, Lecocq X (2010) Business Model Evolution. In Search of Dynamic Consistency. Long Range Plan 43:227-246. doi:10.1016/j.lrp.2010.02.004

Ehrenhard M, Wijnhoven F, van den Broek T, Stagno MZ (2017) Unlocking how start-ups create business value with mobile applications: development of an app-enabled business innovation cycle. Technol Forecast Soc Change 115:26-36. doi:10.1016/j.techfore.2016.09.011

Eschenbaecher J, Wiesner S, Thoben K-D (2014) Validation of innovative extended product concepts for E-mobility. Evolutionary paths towards the mobility patterns of the future. Springer, Berlin, pp 131-152

Frenken K (2015) Towards a prospective transition framework. A co-evolutionary model of sociotechnical transitions and an application to car sharing in The Netherlands. In: International workshop on the sharing economy, Utrecht

Garud R, Kumaraswamy A, Karnøe P (2010) Path dependence or path creation? J Manag Stud 47:760-774. doi:10.1111/j.1467-6486.2009.00914.x

Germany Trade \& Invest (2016) Industry overview. The automotive industry in Germany. Issue 2016/2017. Berlin

Gerwig C, Behrens D, Knackstedt R, Lessing H (2014) Innovatives eCarSharing-Konzept am Beispiel des Hildesheimer Tandem-Modells. In: Plödereder E, Grunske L, Schneider E, Ull D (eds) Lecture notes in informatics. Gesellschaft für Informatik, Bonn, pp 1617-1629

International Transport Forum (2015) Urban Mobility System Upgrade-How shared self-driving cars could change city traffic. Paris

Klepper S (1996) Entry, exit, growth, and innovation over the product life cycle. Am Econ Rev $86: 562-583$

Loose W (2010) The state of European car-sharing. Final report D 2.4 work package 2

Loose W (2014a) Wie alles anfing-CarSharing als Reaktion auf die Verkehrs- und Umweltsituation in den 90er Jahren. In: Eine Idee setzt sich durch! 25 Jahre CarSharing. ksv kölner stadt- und verkehrsverlag, Köln, pp 11-15

Loose W (2014b) Vom Solidarhandeln zur Marktorientierung-25 Jahre CarSharing im Überblick. In: Eine Idee setzt sich durch! 25 Jahre CarSharing. ksv kölner stadt- und verkehrs-verlag, Köln, pp 17-27

Loose W (2016) Mehr Platz zum Leben-wie CarSharing Städte entlastet. Ergebnisse des bcs-Projektes CarSharing im innerstädtischen Raum-eine Wirkungsanalyse Endbericht. Berlin

Markides C, Charitou CD (2004) Competing with dual business models: a contingency approach. Acad Manag Exec 18:22-36. doi:10.5465/AME.2004.14776164

Markides C, Sosa L (2013) Pioneering and first mover advantages: the importance of business models. Long Range Plan 46:325-334. doi:10.1016/j.lrp.2013.06.002 
Martin EW, Shaheen SA (2011) Greenhouse gas emission impacts of carsharing in North America. IEEE Trans Intell Transp Syst 12:1074-1086. doi:10.1109/TITS.2011.2158539

Morris M, Schindehutte M, Allen J (2005) The entrepreneur's business model: toward a unified perspective. J Bus Res 58:726-735. doi:10.1016/j.jbusres.2003.11.001

Murmann JP, Frenken K (2006) Toward a systematic framework for research on dominant designs, technological innovations, and industrial change. Res Policy 35:925-952. doi:10.1016/j.respol.2006. 04.011

Nijland H, van Meerkerk J (2017) Mobility and environmental impacts of car sharing in The Netherlands. Environ Innov Soc Transit. doi:10.1016/j.eist.2017.02.001

Osterwalder Alexander, Pigneur Y (2010) Business model generation: a handbook for visionaries, game changers, and challengers. Wiley, Hoboken

Patzelt H, zu Knyphausen-Aufseß D, Nikol P (2008) Top management teams, business models, and performance of biotechnology ventures: an upper echelon perspective. Br J Manag 19:205-221. doi:10.1111/j.1467-8551.2007.00552.x

Prettenthaler FE, Steininger KW (1999) From ownership to service use lifestyle: the potential of car sharing. Ecol Econ 28:443-453. doi:10.1016/S0921-8009(98)00109-8

Schwarz J, Zielstorff H, Rabold T (2014) GarSharing-Technik von den Anfängen bis heute. In: Eine Idee setzt sich durch! 25 Jahre CarSharing. ksv-verlag, Köln, pp 77-87

Shaheen S, Cohen A (2013) Carsharing and personal vehicle services: worldwide market developments and emerging trends. Int J Sustain Transp 7:5-34. doi:10.1080/15568318.2012.660103

Shaheen S, Sperling D, Wagner C (1998) Carsharing in Europe and North America: past, present, and future. Transp Q 52:35-52. doi:10.1068/a201285

Shaheen S, Cohen A, Roberts J (2006) Carsharing in North America: market growth, current developments, and future potential. Transp Res Record J Transp Res Board 1986:116-124. doi:10. 3141/1986-17

Shaheen SA, Mallery MA, Kingsley KJ (2012) Personal vehicle sharing services in North America. Res Transp Bus Manag. doi:10.1016/j.rtbm.2012.04.005

Shaheen S, Chan N, Bansal A, Cohen A (2015) Shared mobility. Definitions, industry developments, and early understanding. University of California Berkeley Transportation Sustainability Research Center, Berkeley. http://innovativemobility.org/wp-content/uploads/2015/11/SharedMobility_ WhitePaper_FINAL.pdf

Shapiro C, Varian HR (1999) Information Rules-A strategic guide to the network economy. Libr Congr Cat Data 14

Sosna M, Trevinyo-Rodríguez RN, Velamuri SR (2010) Business model innovation through trial-anderror learning. Long Range Plan 43:383-407. doi:10.1016/j.lrp.2010.02.003

Teece DJ (2010) Business models, business strategy and innovation. Long Range Plan 43:172-194. doi:10.1016/j.lrp.2009.07.003

Utterback JM (1996) Mastering the dynamics of innovation: how companies can seize opportunities in the face of technological change. Long Range Plan 6:908-909

Utterback JM, Suárez FF (1993) Innovation, competition, and industry structure. Res Policy 22:1-21. doi:10.1016/0048-7333(93)90030-L

Vaskelainen T (2014) Sustainable business models-The case of car sharing. In: Resilence-the new research frontier: Proceedings of the 20th annual international sustainable development research conference, Norwegian University of Science and Technology; International Sustainable Development Research Society, pp 615-627

Warmke G, Dannheim B (2014) Cambio. In: Eine Idee setzt sich durch! 25 Jahre CarSharing. ksv kölner stadt- und verkehrs-verlag, Köln, pp 29-40

Zott C, Amit R, Massa L (2011) The business model: recent developments and future research. J Manag 37:1019-1042. doi:10.1177/0149206311406265 